\title{
IDENTIFYING STUDENTS' SCIENTIFIC ARGUMENTATION SKILL AT JUNIOR HIGH SCHOOL 1 ARGAMAKMUR, NORTH BENGKULU
}

\author{
Mentari Darma Putri ${ }^{1 *}$, Dadi Rusdiana ${ }^{2}$ \\ ${ }^{1}$ Ms., Indonesia University of Education, INDONESIA, mentari darmaputri@student.upi.edu \\ ${ }^{2}$ Dr., Indonesia University of Education, INDONESIA, dadirusdiana@upi.edu \\ *Awardee Master Candidate of Indonesian Endowment Fund for Education (LPDP) Scholarship
}

\begin{abstract}
This is a preliminary study aimed to identify students' scientific argumentation skill at Junior High School 1 , Argamakmur, North Bengkulu. The data were gathered by online survey to 8 science teachers in Bengkulu and test to 32 students of grade eight in Junior High School 1, Argamakmur, North Bengkulu. Online survey consisted of 4 questions focused on science learning issues. The essay test to obtain scientific argumentation skill consisted of 4 questions, where each question was covering four indicators of scientific argumentation: claim, data, warrant and backing. A valid scientific argumentation test was adopted from Putri (2016). Data were analyzed using descriptive statistics by calculating the percentage of average score of teacher answers and students' scientific argumentation skill as a whole. The data analysis revealed that the teachers argue that students' scientific argumentation skill was still very low compared to others skill like the science process skill, critical thinking skill, creative thinking skill, scientific literacy skill and student independence and this statement supported by test result where the score of students' argumentation skill achieved low category. This phenomenon might be caused by the lack of educational learning process that facilitates students in expressing their opinions according to scientific evidence both orally and in writing. This paper also offers an idea helping teachers to improve students' scientific argumentation skill by implementing phenomenon-based learning with video assistance through a modified "flipped classroom" approach.
\end{abstract}

Keywords: Scientific Argumentation, Students' Scientific Argumentation Skill

\section{INTRODUCTION}

One of the epistemic and conceptual goals of science learning is to construct students' argumentation skill (Duschl \& Osborne, 2002). The purpose of science education is not only to lead students to master the scientific concept but also to engage them in scientific discussion (Bricker \& Bell, 2009). The essential of argumentation is not in line with its implementation in science classroom. Teachers have not comprehensively applied scientific argumentation in science classes due to several factors (Driver et al., 2000). Many studies reveals that students' difficulties in formulating arguments are caused by lack of 
participation in scientific discussions and limitations of teachers' pedagogical competence to support argumentative activities such as the lack of teacher ability to initiate and manage the course of discussion (Newton et al., 1999; Duschl \& Osborne, 2002 ). The purpose of this study was to identify teacher perception on science learning issues in Bengkulu, problems and solutions. The secondary purpose was to identify background of students' scientific argumentation skill at Junior High School 1, Argamakmur, North Bengkulu. The outcome of this study is important to educators as they make decision about the best ways to improve students' scientific argumentation skill in science learning.

The reseach questions included:

(1) What perceptions do teachers have about science learning issues in Bengkulu?

(2) How is the students competence in doing argumentation in science class?

\section{Scientific Argumentation}

Scientific argumentation is the process of making claims justified by the support of scientific evidence. The purpose of argumentation in science is to form arguments that explain the relationship between idea and evidence (Duschl, Schweingruber, \& Shouse, 2007 in Sampson \& Gerbino, 2010). Argumentation activity is an effective way to develop students' conceptual understanding in science (Driver et al., 2000; JimenezAleixandre, Rodriguez, \& Duschl, 2000). Kelly \& Chen (1999) argue that discourse processes are effective in building knowledge, and learning occurs through discourse in the classroom. "Speaking provides an opportunity to guess, argue, and challenge. By speaking, the students will excuse reason to support their conceptual understanding and try to justify their views. Other students will oppose, express doubts, and seek alternative answers so that clearer conceptual understanding will emerge" (Newton et al., 1999).

According to the framework of Toulmin's Argument Pattern (TAP), an argument includes six components: claim, data, qualifier that indicates the power of claim, warrant that explains the relationship between claim and data, backing that stregthens warrant, and rebuttal that indicates exceptions or limitations of claim (Simon, 2008). Three principal components of the argument are claim, data, and warrant. Stronger argument contains backing which explains how argument has authority and provides validity to the core of the argument. Other components that may appear in more complex arguments are rebuttal which is a counterclaim as well as denial of argument components and qualifier which is limited statement describes that the claim is true (Kulatunga et al., 2013). Furthermore, indicator of the argumentation skill aspects can be shown in Table 1.

Table 1. Argumentation Skill Aspects

\begin{tabular}{|c|c|c|}
\hline $\begin{array}{l}\text { Argumentation } \\
\text { Aspects }\end{array}$ & Indicator & Description \\
\hline Claim & $\begin{array}{l}\text { Making a claim appropriate } \\
\text { to the problem }\end{array}$ & $\begin{array}{l}\text { - Making accurate claim } \\
\text { appropriate to the problem } \\
\text { - Articulating correct claim based } \\
\text { on a particular field of study or } \\
\text { discipline } \\
\text { - Articulating claim with good and } \\
\text { correct language structure }\end{array}$ \\
\hline Data & $\begin{array}{l}\text { Giving and analysing data } \\
\text { to support claim }\end{array}$ & $\begin{array}{l}\text { - } \quad \text { Giving appropriate data (based on } \\
\text { observations, measurements and } \\
\text { so on) and supporting the claim } \\
\text { - Giving adequate data (based on } \\
\text { observations, measurements and } \\
\text { so on) both in quality and quantity } \\
\text { - Analysing data to support claim }\end{array}$ \\
\hline Warrant & $\begin{array}{l}\text { Explaining the relationship } \\
\text { between data and claim }\end{array}$ & $\begin{array}{l}\text { Describing the logical relationship } \\
\text { between data and claim (such as } \\
\text { analogy, causation, comparison and } \\
\text { so on) }\end{array}$ \\
\hline Backing & $\begin{array}{l}\text { Underlying justification or } \\
\text { warranties to support the } \\
\text { claim }\end{array}$ & $\begin{array}{l}\text { Proposing principles, laws, concepts, } \\
\text { or theories that support justification or } \\
\text { warranties }\end{array}$ \\
\hline
\end{tabular}

(Sampson \& Gerbino, 2010)

The structure of the argument can be coded using the rubric from Erduran et al., (2004) consisting of five levels as described below. 
Table 2. Levels of Argumentation

\begin{tabular}{|c|l|}
\hline $\begin{array}{c}\text { Levels of } \\
\text { Argumentation }\end{array}$ & \multicolumn{1}{c|}{ Description } \\
\hline Level 1 & $\begin{array}{l}\text { Argumentation consists of arguments that are a simple claim versus a } \\
\text { counter-claim or a claim versus a claim }\end{array}$ \\
\hline Level 2 & $\begin{array}{l}\text { Argumentation has arguments consisting of a claim versus a claim with } \\
\text { either data, warrants, or backings but do not contain any rebuttals }\end{array}$ \\
\hline Level 3 & $\begin{array}{l}\text { Argumentation has arguments with a series of claims or counter-claims } \\
\text { with either data,warrants, or backings with the occasional weak rebuttal }\end{array}$ \\
\hline Level 4 & $\begin{array}{l}\text { Argumentation has arguments with a claim with a clearly identifiable } \\
\text { rebuttal. Such an argument may has several claims and counter-claims }\end{array}$ \\
\hline Level 5 & $\begin{array}{l}\text { Argumentation displays a next ended argument with more than one } \\
\text { rebuttal }\end{array}$ \\
\hline
\end{tabular}

\section{RESEARCH METHODS}

This study is a preliminary study of the author's thesis research plan. In this study, researcher used a descriptive approach. This study was prepared based on the results of online survey and students test. The online survey has been given to eight science teachers from eight Junior High Schools in Bengkulu province, namely Junior High School 62 North Bengkulu; Junior High School 13 North Bengkulu; Junior High School 4 Taba Penanjung, Central Bengkulu; Alkarim Junior High School Bengkulu; Junior High School 2 Pondok Kelapa, Central Bengkulu; Junior High School 1 North Bengkulu; Junior High School 1 Ujan Mas; Junior High School 2 Topos. The online survey contained four questions focused on science learning issues developed by the researcher.

Research data were also obtained from student test results. The test was aimed to identify students scientific argumentation skill. The subject of the test was the students of grade eight at Junior High School 1, Argamakmur, North Bengkulu, amounting to 32 students, consisting of 17 female students and 15 male students. The procedure for conducting the students argumentation data began by adopting the scientific argumentation question on heat and global warming topics developed by Putri (2016). The test consisted of four questions where each question covering four indicators of scientific argumentation: claim, data, warrant and backing. The next step was to spread the problem to students by science teacher. Test results were then analyzed to get a conclusion. The results of the scientific argumentation test were analyzed using argumentation score rubric developed by Sampson and Gerbino (2010).

\section{RESULTS AND DISCUSSION}

\subsection{Results}

This research is a preliminary study to find out the problems faced by science teachers in teaching science in Bengkulu. The research data was obtained from the results of the online survey that researcher gave to eight Junior High School teachers in Bengkulu. The online survey contained four questions developed by researcher. The survey questions were the usual method applied by teachers in teaching science, difficulties and constraints commonly faced by teachers in teaching science, students' skills were still low according to teachers, and the needed of teachers in overcoming the problem of teaching science. Here are the answers to each survey question.

\section{Online Survey Results}

The first question on the online survey was the usual method applied by teachers in teaching science. There were eight alternative answers: lecture, discussion, demonstration, practice, role playing, project, outdoor and other activities. Respondents might choose more than one answer. Respondents mostly chose demonstration method as the method they often used in teaching science.

The second question on the online survey was the difficulties and constraints commonly faced by teachers in teaching science. Respondents were given alternative answers such as lack of availability of tools and practicum materials, unavailability of special laboratory science, students with the tendency of low level of ability, the absence of officers who helped to create an effective laboratory activity, science laboratories that switched functions into classrooms so it could not be maximally utilized, as well as other answer choices filled by respondents if there were other causes of difficulties or obstacles they faced in teaching science. Respondents might choose more than one answer. Based on the answers from the respondents, it was found that $40 \%$ of teachers believed that the difficulties in teaching science was caused by the lack of tools and practicum materials, $30 \%$ due to the low ability of students, $15 \%$ due to the unavailability of special laboratory science, so that the lab became ineffective, the science lab turned the function into a classroom 
so it could not be utilized maximally. Meanwhile, for the other answer choices each contributed $5 \%$ to the cause of teachers' difficulties in teaching science. It appeared that the lack of availability of tools and practicum materials was the main factor causing difficulties or constraints commonly faced by teachers in teaching science.

The third question on the online survey was the students' skills were still low according to teachers. There were six choices of answers that could be selected by the respondents namely the science process skill, scientific argumentation skill, critical thinking skill, creative thinking skill, scientific literacy skill and student independence. The highest percentage that was $22 \%$ refers to the scientific argumentation skill. According to the teacher, their students scientific argumentation skill was the lowest category compared to other skills.

The fourth question on the online survey was the needed of teachers in overcoming the problem of teaching science. There were five alternative answers namely interesting and innovative learning media, alternative assessment in science learning, application of active learning models, teacher teaching materials, and others. The highest percentage, $46 \%$ represented the answer chosen that was interesting and innovative learning media, then $27 \%$ chose teacher teaching materials, $20 \%$ chose alternative assessment in science learning and $7 \%$ chose facilities and infrastructure. This showed that according to the teacher's response, the most urgent need in overcoming the problem of science learning that was needed of existence of interesting and innovative learning media of science.

\section{Results of Scientific Argumentation Test}

From the data of online survey results, it was found that according to the teacher, the students argumentation skill was still very low. To reinforce the teacher's opinion, the researcher then gave scientific argumentation test to 32 students of grade eight at Junior High School 1 Argamakmur, North Bengkulu where the teacher being respondent taught. The test consisted of 4 questions. Each question contained a discourse related to the phenomenon of heat and global warming. From the discourse, the students were asked to fill 4 questions related to the 4 aspects in scientific argumentation namely writing the claim, involving the evidence, explaining the relationship between data and claim, and underlying justification to support the claim. This scientific argumentation test was adopted from thesis Putri (2016), postgraduate student of science education study program in Indonesia University of Education which content and field had been validated. Here was one example of the scientific argumentation skill test:

Discourse: Today the temperature in Padang city shows the number of $32^{\circ} \mathrm{C}$. Ani plans to hang clothes so that she can wear that clothes tomorrow. There are three different clothes with different colors. The three clothes are black, white and yellow. In your opinion, from the three clothes, which clothes will be dry first?

1. Give your statement to answer the question above. (Claim)

2. Give examples of your daily observations to support your statement. (Data)

3. Explain the relationship between the statement and the example you gave (number 1 and 2) (Warrant)

4. Explain the theory that can be used to support your answer! (Backing)

From the test of scientific argumentation skill that has been tested, the result of the average score of students' scientific argumentation skill as a whole was 24,7 from maximum score 48 , that belong to low category. Student who got score less than 12 was one person, that belong to very low category; students who got score from 13 until 24 were 18 people, that belong to low category; students who got score from 25 until 36 were 10 people, that belong to intermediate category and students who got score above 37 were three people, that belong to high category. From all the categories, most students in the classroom had low scientific argumentation skill.

\subsection{Discussion}

Many problems faced by teachers in teaching science. Based on the survey result previously described, eight teachers from eight different Junior High Schools in Bengkulu agreed that the lack of facilities and infrastructure such as tools and lab materials, inadequate science laboratories, the absence of specialized laboratory staff who assist in preparing the practicum becomes the main obstacle faced by teachers in teaching science. In fact, practicum activity is important in learning science because it can develop students' thinking skills in building scientific concepts (Rustaman, 1996). The factor of inadequate tools and lab materials makes the teacher prefer lecture and demonstration methods in teaching science that impact on the low ability of students in science.

Based on the survey result previously presented above, according to the teachers, the lowest ability of their students was the scientific argumentation skill. The teachers' perceptions were also supported by the results 
of the scientific argumentation test from 32 students of grade eight where it was found that the students' overall scientific argumentation result was belonging to low category. Based on the analysis of student answers was found that overall students could make simple claim according to the problem although there were some student with incorrect claim to the problem. For question number one, 30 students responded with the wrong claim, only two students wrote the true claim. For question number three, 15 students gave the correct claim, and 17 others gave the wrong claim. For question number four, 12 students made correct claim while the others wrote the wrong claim. While in question number two, all students gave the correct claim. Interestingly, in the case of problem number one, it could be seen that there were misconceptions in students' answers where 30 students believed that white clothes dried faster than black and yellow. Students argued that white clothes more quickly absorbed sunlight than black and yellow color did. Meanwhile, the correct answer was that black clothes dried faster because black color more quickly absorbed sunlight while the white color was highly reflective toward the sunlight.

Based on the analysis of student answers, it was known that students could give evidence to support claim according to their daily experience but most of the evidences were inadequate both in quality and quantity. Students also could not be able to provide a justification that explains the logical relationship between the data and the claim they made. In addition, an important aspect of the argumentation was backing that underlying justification or warranties to support the claim. Backing could be in the form of proposing principles, laws, concepts or theories that supported justification. From the students' overall average answers, it was found that the students felt difficult to provide backing to support their claims.

The low ability of students in scientific argumentation was due to the lack of student participation in scientific discussions. Most teachers used demonstration method in science learning whereas students needed to conduct their own experiments to look for evidence in the form of data supporting their claims toward science phenomena. According to Yamin (2008) the demonstration method becomes less effective if it is not followed by an activity where learners can participate in the experiment and make the activity as a personal experience.

The argumentation skill is actually naturally owned by the students, but not specifically developed in the school curriculum. Schools should ensure students develop skills in formulating opinions independently, empirically, rationally, and critically (Christenson, Rundgren, Hoglund, 2012; Venville and Dawson, 2010a). However, the facts in the field, students argumentation skill in science learning at Junior High School in Bengkulu is still relatively low (Defianti, 2016). Therefore, it is needed of teachers role in helping students to develop their argumentation skill. According to Venville and Dawson (2010b), to develop argumentation skill, teachers need to use appropriate strategies. One of them can be by applying scientific discussion activities in the classroom.

Practicing arguing through group discussion activities was an effective way to develop the basic skills of students' argumentation. In group discussions, students communicated their statements or opinions about something and then gave reasons or arguments for their explanations to be stronger and scientific (Osman, Chuo Hiong, \& Vebrianto, 2013). It was also supported by Golanics and Nussbaum (2008) who observed that collaborative argumentation through discussion activities was important in an educational context because it could help students explored relationships between ideas, changed student conceptions, negotiated for evidence of statements or claims. Kelly \& Chen (1999) also argues that discourse is effective in building knowledge, and learning occurs through discourse in the classroom. "Speaking provides an opportunity to guess, argue, and challenge. By speaking, the students will excuse reason to support their conceptual understanding and try to justify their views. Other students will oppose, express doubts, and seek alternative answers so that clearer conceptual understanding will emerge "(Newton, Driver, \& Osborne, 1999).

\section{Recommendation}

For that reason, to develop students' scientific argumentation skill, teachers need to apply science learning that can facilitate students to argue. One of science learning model that can be implemented is phenomenon-based learning with video assistance through a modified "flipped classroom" approach. In phenomenon-based learning, students are involved in a series of scientific activities through the stages of learning. In the early stages of student orientation on phenomena observation, students are asked to observe the phenomenon of science through video display. From the observation of the phenomenon, students will think about the phenomenon they saw, why the phenomenon can occur or what causes the phenomenon can occur. The teacher's job at this stage is to motivate students to express their ideas and opinions about the phenomenon they see and explain that the phenomenon can be explained scientifically by conducting an investigation through experimental or scientific experiments. After students conducted an investigation activities through experiments to find an explanation of the causes of the occurrence of science 
phenomena and scientific theories that explain it, the next phases of phenomenon-based learning is to develop and present the work. At this stage, students are given the opportunity in groups to present their group experimental results. The teacher guides the class discussion, in which the other students respond to the group's statement of the presentation, approves or refutes the statement if it is not in accordance with the outcome of their group. This class discussion aims to get a true and complete explanation of the material being studied so that all students gain the same understanding. This is consistent with the explanations of Erduran, Simon, \& Osborne (2004) that science learning is not only about how natural law occurs or how the universe exists but also focuses on the explanations of how the universe will be in the future. Thus, learning science begins with a discussion of the main reasons for facts and natural theories. So hopefully from this scientific discussion activity can improve students' scientific argumentation skill.

\section{CONCLUSION}

Based on the background of problems faced by science teachers from several Junior High Schools in Bengkulu province and scientific argumentation test, it was found that according to the teacher, the students argumentation skill was still very low. This perception supported by the results of scientific argumentation test toward 32 students of grade eight at Junior High School 1, Argamakmur, North Bengkulu where the result of the average score of students' scientific argumentation skill as a whole was belong to low category. The low ability of students in scientific argumentation was due to the lack of student participation in scientific discussions so that teachers needed to develop students' scientific argumentation skill through implementation of science learning that could facilitate students to argue. This study recommends the idea to apply phenomenon-based learning with video assistance through a modified "flipped classroom" approach to improve students' scientific argumentation skills.

\section{ACKNOWLEDGEMENT}

In accomplishing this article, through this acknowledgement the writer would like to present my greatest gratitude to LPDP (Indonesia Endowment Fund for Education) that recently funds my study of master's degree and to numerous people whose support and advise me were psychologically encouraging me during writing this article. I would like to express my special gratitude to: my lecturers, my parents and all of my friends (Science Education Class B, Master's Students of Science Education Program, UPI and LPDP Awardess in Bandung).

\section{REFERENCE LIST}

Bricker, L., \& Bell, P. (2009). Conceptualizations of Argumentation from Science Studies and the Learning Sciences and their Implications for the Practices of Science Education. Science education, 92(3), 473498.

Christenson, N., Rundgren, S.N.C., \& Hoglund, H.O. (2012). Using the See-Sep Model to Analyze Upper Secondary Students' Use of Supporting Reason in Arguing Socioscientific Issues. Journal Science Education Technology, 21. p. 342-352.

Defianti, Aprina. (2016). Penerapan Model Pembelajaran Pembangkit Argumen menggunakan Multiple External Representations untuk Meningkatkan Kemampuan Kognitif dan Keterampilan

Berargumentasi Siswa SMP. (Thesis). School of Postgraduate, Indonesia University of Education, Bandung.

Driver, R., Newton, P., \& Osborne, J. (2000). Establishing The Norms Of Scientific Argumentation In Classrooms. Science Education, 84(3), 287-312.

Duschl, R. A., \& Osborne, J. (2002). Supporting And Promoting Argumentation Discourse In Science Education. Studies In Science Education, 38(1), 39-72.

Erduran, S., Simon, S., \& Osborne, J. (2004). Enhancing The Quality Of Argumentation In School Science. Journal of Research in Science Teaching, 41(10), 994-1020.

Golanics \& Nussbaum, E. M. (2008). Collaborative Discourse, Argumentation, And Learning: Preface And Literature Review. Contemporary Educational Psychology, 33(3), 345-359.

Jimenez-Aleixandre, M. P., Rodriguez, A. B., \& Duschl, R. A. (2000). "Doing The Lesson" Or "Doing Science": Argument In High School Genetics. Science Education,84(6), 757e792.

Kelly, G. J., \& Chen, C. (1999). The Sound Of Music: Constructing Science As A Sociocultural Practices Through Oral And Written Discourse. Journal Of Research In Science Teaching, 36(8), 883 - 915. 
Kulatunga, U., Moog, R. S. \& Lewis, J.E. (2013). Argumentation and Participation Patterns in General Chemistry Peer-Led Sessions. Vol. 50. No. 10,pp. 1207-1231. United States of America: Journal of Research in Science Teaching.

Newton, P. Driver, R. \& Osborne, J. (1999). The Place Of Argumentation In The Pedagogy Of School Science. International Journal Of Science Education, 21(5), 553-576.

Osman, Chuo Hiong, \& Vebrianto. (2013). 21 ${ }^{\text {st }}$ Century Biology: An Interdisciplinary Approach of Biology, Technology, Engineering and Mathematics Education. Procedia-Social and Behavioral Sciences 102 (2013) 188-194.

Putri, Rahmah Evita. (2016). Meningkatkan Penguasaan Konsep dan Kemampuan Argumentasi Ilmiah Siswa SMP Kelas VII Melalui Bahan Ajar IPA Terpadu dengan Tema Halo pada Topik Kalor. (Thesis). School of Postgraduate, Indonesia University of Education, Bandung.

Rustaman, N. (1996). Peranan Praktikum dalam Pembelajaran Biologi. Training and Technician Training Papers FPMIPA IKIP Bandung.

Sampson \& Gerbino. (2010). Argument-Driven Inquiry as a Way to Help Students Learn How to Participate in Scientific Argumentation and Craft Written Arguments: An Exploratory Study. Science Education, 95, page 217-257.

Simon, S. (2008). Using Toulmin's Argument Pattern In The Evaluation Of Argumentation In School Science. International Journal of Research \& Method in Education, 31(3), $277 \mathrm{e} 289$. http://dx.doi.org/10.1080/17437270802417176.

Venville, G.J., \& Dawson, V.M. (2010a). The Impact of Classroom Intervention on Grade 10 Students' Argumentation Skills, Informal Reasoning, and Conceptual Understanding of Science. Journal of Research in Science Teaching, 47. (8), p. 952-977.

Venville, G.J., \& Dawson, V.M. (2010b). Teaching Strategies for Developing Student's Argumentation Skills About Sosio-Scientific Issues in High School Genetics. Research in Science Education, vol.42, p. 133148.

Yamin, Martinis. (2008). Desain Pembelajaran Berbasis Tingkat Satuan Pendidikan. Jakarta: Gaung Persada Press. 